\title{
EL DIÁLOGO DE MARÍA ZAMBRANO CON UNAMUNO Y ANTONIO MACHADO, FILOSOFÍA PRIMERA PARA LA CULTURA ACTUAL
}

\author{
ANTONIO SÁNCHEZ ORANTOS \\ Universidad Pontificia Comillas
}

\begin{abstract}
RESUMEN: La presencia de Unamuno y Antonio Machado en la propuesta filosófica de María Zambrano invita a redefinir la filosofía primera como tarea que todo ser humano debería asumir para dar pleno cumplimiento a la llamada que, manifestándose en su interioridad, invita a hacerse cargo de la alteridad y, por eso, piedad y misericordia, a fundar adecuadamente caminos de diálogo en busca de esa verdad, que por no uniformar y sí pedir unidad, abre proyectos de verdadera comunidad: diferentes buscando fraternidad.
\end{abstract}

PALABRAS CLAVE: Unamuno; Antonio Machado; filosofía primera; poesía; estética; ética; diálogo.

\section{Maria Zambrano's dialogue with Unamuno and Antonio Machado, First Philosophy for our current culture}

\begin{abstract}
The presence of Unamuno and Antonio Machado in Maria Zambrano's philosophical proposal is an invitation to redefine first philosophy as a task which every human being should assume in order to fully comply to the call which, manifesting in their interiority, invites them to take responsibility for otherness, and thus, piety and mercy, to adequately establish the paths of dialogue in search of that truth, which by seeking unity, but not uniformity, opens projects of true community: different people seeking fraternity.
\end{abstract}

KEY WORDS: Unamuno; Antonio Machado; first philosophy; poetry; aesthetics; ethics; dialogue.

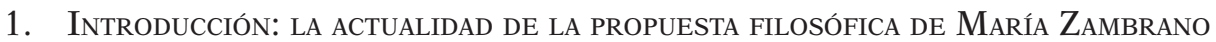

La filosofía de Zambrano es una búsqueda continua de una filosofía primera que permita al ser humano enfrentar con verdad sus crisis en el tiempo de la vida, sin huidas a transmundos ilusorios, invitando a un novedoso (re) nacimiento que impide que esos acontecimientos que desnudan la vida humana la aboquen o al artificio de la novelería o a la resignación senequista o al pesimismo trágico: quiebra de toda esperanza. Por eso, no puede ser remitida sin más a la sabiduría gnóstica y más cuando aquellos que la adscriben a tal corriente filosófica se ven obligados a añadir, inmediatamente, y con razón, "evitando todo dualismo», que como es sabido constituye uno de los núcleos fundamentales del gnosticismo. Pero, además, nuestra pensadora deja escrito:

«Primeramente en su actitud más ingenua, (el poeta) no se hará problema de su relación con la realidad que le enamora; después de que el inevitable fracaso de toda vida haya surgido, cuando haya aparecido aunque sea no más que la conciencia de vivir embebido en su puro arrobamiento aparecerá entonces el problema de su relación con esa realidad. Mas entonces no pide liberarse de ella, sino tenerla de alguna otra manera... (Tal vez sea ésta) la raíz de la mística española tan diferente de la mística alemana, a la que hay que 
considerar como prototipo de la mística europea. La mística alemana predecesora de la Reforma protestante, parte de la soledad absoluta del hombre frente a la tiránica voluntad divina, es mística asentada en el esfuerzo angustioso por consolidar la existencia, es mística de náufragos, de agonizantes que se agarran a la indescifrable potencia de Dios; en esa mística no aparece como en la nuestra la misericordia; ni tampoco la presencia maravillosa del mundo y sus criaturas, como en San Juan de la Cruz. Ni la carne, con su palpitar la materia misma de las cosas consideradas maternalmente como en Santa Teresa. El místico norteño es un hombre solo, que en su absoluta soledad no es ni padre ni hijo, ni tal vez hermano, está más cerca de la angustiosa filosofía idealista que tiene en ellos con toda seguridad, su raíz.» ${ }^{1}$

Se trata, pues, ciertamente, de remitir su propuesta a una olvidada Sabiduría, olvidada e incluso quebrada por el racionalismo moderno — aunque de apertura mística sepa mucho la propuesta de Pascal y el movimiento romántico-, que tiene que ver con el palpitar de la materia misma, con la presencia maravillosa del mundo y sus criaturas, con la carne que sabe de maternidad/paternidad y, por eso, de hermandad. Es la razón poética cuyo método permite mirar de manera nueva la alteridad y sus sucesos, porque se enraiza en una Presencia donada en la intimidad humana, sólo presentida; ya que dicha Presencia abre la experiencia de trascendencia, no-posesión, y, por eso, será sentida como Ausencia, no dominable, ni representable, pero que provoca a la voluntad, llamada (voz) esperanzada, a la búsqueda constante de verdadera vida humana: excelencia humana a distancia, nunca lograda, siempre buscada. Senderos de sabiduría que exigen Confesión y Guía.

«Cada época se justifica en la historia por el encuentro de una verdad que alcanza claridad en ella. ¿Cuál será nuestra verdad? ¿Cuál nuestra manifestación?...Desde la Filosofía que emplea sus racionales instrumentos en arrojar luz sobre la Ciencia, "Ciencia de las ciencias", se ha vuelto, sin desperdiciar su herencia, a eso escalofriante de puro maravilloso que es que la Filosofía, el pensamiento en su mayor pureza, se arroje con el ímpetu de la pasión, no para devorarse a sí misma, como la pasión sólo hace, sino para detenerse a tiempo, antes de que la caza huya y traérnosla intacta. La pasión sola ahuyenta a la verdad, que es susceptible y ágil para evadirse de sus zarpas. La sola razón no acierta a sorprender la caza. Pero pasión y razón unidas, la razón disparándose con ímpetu apasionado para frenar en el punto justo, puede recoger sin menoscabo a la verdad desnuda. Entonces es la Filosofía, como decía Platón hablando de Protágoras, "camino de vida".»²

Se trata, en definitiva, de salir de la estrecha definición que la modernidad establece para el quehacer filosófico recuperando lo que desde el origen quiso ser el amor a la sabiduría: un saber crítico frente a lo que se dice, se mantiene y se afirma, opiniones sin fundamento (ironía socrática); que situando al hombre

1 M. Zambrano, Pensamiento y poesía en la vida española, Obras Completas I. Galaxia Gutenberg, Barcelona, 2015, pp. 136-137.

2 M. Zambrano, Hacia un saber sobre el alma, Obras Completas II. Galaxia Gutenberg, Barcelona, 2016, p. 433. 
en su intimidad más íntima (conócete a ti mismo: salida de la actitud natural); le posibilitase descubrir un orden, un canon, una medida (vida ética: órfico pitagórica); que venciendo la arrogante fuerza del Hay natural; abriese su vida a la experiencia del Bien (Platón), no sólo del Ser, para lograr su excelencia presentida: Camino de vida.

\section{LA NOBLE PERO INSUFICIENTE TAREA DE LA «RAZÓN INSTRUMENTAL»: LA ATENCIÓN A «LA REALIDAD DE LA VIDA»}

Se ha dicho que la filosofía, el amor a la sabiduría, tiene como punto de partida la admiración; pero si así fuera, y estamos nombrando una de las principales convicciones de la propuesta de María Zambrano, nunca podrá explicarse por qué ese empeño de reducirla a ese género de mirada: la abstracción, que abandona inmediatamente las singulares maravillas que ofrece a la sensibilidad el mundo de la vida.

«Porque la admiración que nos produce la generosa existencia de la vida en torno nuestro no permite tan rápido desprendimiento de las múltiples maravillas que la suscitan. Y al igual que la vida, esta admiración es infinita, insaciable y no quiere decretar su propia muerte.» ${ }^{3}$

Debe, pues, suponerse otro principio, que junto a la admiración, esté determinando la dirección del pensar humano, y que poco tiene que ver con el hospedar amoroso de la maravilla, y mucho con la necesidad de control, de fuerza, de poder, de violencia. Y es que el ser humano, y de esto también conviene maravillarse, para hacer viable su vida tiene que, debe, convertir la naturaleza inhóspita en un espacio habitable, en un humano lugar, en un hogar. Es la ley que impone la Evolución. Ley, y esta es la maravilla, que permite comprender, más adelante lo veremos afirmado con belleza en la propuesta de Machado, que el hombre exigido por la realidad natural no queda determinado por ella. Es la belleza, primero de la técnica y, después, de la ciencia y la unidad de ambas: la tecnología. Gracias a estos maravillosos saberes, el ser humano puede atender a la realidad de su vida, abrir camino propio en el seno de la realidad natural: vivir gozando de la vida o, si se quiere, vivir reduciendo el sufrimiento que el Hay natural impone.

Es la sabiduría de Unamuno, presente, muy presente en la propuesta de Zambrano, que deja escritas palabras que siempre deberían guiar el verdadero saber humano:

«El objeto de la ciencia es la vida, y el objeto de la sabiduría es la muerte. La ciencia dice "hay que vivir", y busca los medios de prolongar, acrecentar, facilitar, ensanchar y hacer llevadera y grata la vida; la sabiduría dice "hay que morir", y busca los medios para prepararnos a bien hacerlo» ${ }^{4}$

3 M. Zambrano, Filosofía y poesía, Obras Completas I. Gutenberg, Barcelona, 2015, p. 689.

4 A. Villar Ezcurra, Miguel de Unamuno. Escritos sobre la ciencia y el cientificismo, Tecnos, Madrid, p. 205. Cf. Unamuno, Sobre la Europeización, mayo-diciembre 1906. 
Porque de eso se trata. No de rechazar la razón y, por eso, el conocimiento científico, sino de prestar suma atención a sus límites. Porque no es Ciencia sino cientificismo «la disposición de espíritu creciente, que consiste en tener una fe ciega en la ciencia. Ciega porque esta fe es tanto mayor, cuanto menor es la ciencia de los que la poseen. $\nu^{5}$ El cientifismo prevalece allí donde la Ciencia lleva una vida lánguida. «Porque aquellos que no se atreven a buscar la vida de las que dicen profesar como verdades, jamás viven con verdad en la vida.» ${ }^{6} \mathrm{Y}$ queda así definida la vocación científica, que obliga a un doble reconocimiento: «que poca ciencia lleva al cientificismo y mucha nos aparta de él» ${ }^{7}$.

No conviene olvidar que la mayoría de las veces la omnipotencia es síntoma de la impotencia. La desconfianza respecto a la exuberancia de la realidad, miedo a su aspecto incontrolable, parece estar invitando a la obligación de construir un saber desligado de todo lo que constituye la enigmática realidad natural, personal y social. Y, desde la modernidad, tal actitud se difunde ampliamente contaminando todo proceder intelectual. Y, entonces, la vida queda anulada por un aparente saber que quiebra la verdadera vocación científica, que nunca podrá ser, repetimos, negación de la razón, pero siempre tendrá que ser reconocimiento de que ésta nace y tiene que mantenerse enraizada en la vida, porque sólo así sus resultados estarán al servicio de la vida y nunca, ni siquiera como posibilidad, procurando su sin-sentido, su destrucción: nihilismo desesperanzado, invitación a un narcisismo que impide toda hermandad con la naturaleza (vida ecológica) y con los demás (vida ética/ política: persona y democracia).

Pero, además, María Zambrano, enseñada por el magisterio de Unamuno, porque solamente él «tuvo el valor de llegar hasta la llaga más honda de nuestra vida, allí donde ya no hay clases sociales» ${ }^{8}$, quiere que veamos en esta violencia racionalista una visión mutilada, falsa interpretación, idolatría, de esa fuente de sentido que siempre ha sido para occidente la sabiduría judeo cristiana.

«La razón (moderna) caminaba por el cauce de una desmedida ambición religiosa. El hombre quería ser. Ser creador y libre. Y seguidamente ser único. Son los pasos, sin duda decisivos de la historia moderna, de eso que propiamente se llama Europa. Y su angustia y su tragedia... La metafísica de la creación... lo que hay en el centro de esta metafísica, como ya se ve no más acercarse a ella, es la acción... la acción que arranca de la voluntad y acaba en el acto de dar forma...»"

«Metafísica de la creación»: un proyecto sumamente ambicioso. Se trata de conocer para dominar y abrir proyectos de autoafirmación sin considerar alteridad alguna. Supone que el ser humano es el fundamento exclusivo de todo

\footnotetext{
$5 \quad$ Ibíd., LVII-LVIII. Cf. Unamuno, Cientificismo, 9 de junio, 1907.

$6 \quad$ Ibid., p. 247, Cf. Unamuno, Verdad y vida, febrero 1908.

7 Ibíd., p. LXII. Cf. Unamuno, Cientificismo, 9 de junio, 1907.

8 M. Zambrano, Unamuno. Edición e introducción de Mercedes Gómez Blesa. Debate, Barcelona, 2003, p.130.

9 M. Zambrano, Filosofía y poesía, o.c., p. 740 (el paréntesis es propio).
} 
lo existente. El ser humano (auto)fundado sin admitir alteridad alguna. Porque el proyecto moderno considera que el esfuerzo humano, la acción, puede alcanzar en el «más acá» el «más allá» al que apunta la inquietud radical humana. Proyecto prometeico, a pesar de la bella advertencia de la poesía romántica. Pretensión de superar la terrible condena de Sísifo. De ahí el tremendo esfuerzo ascético exigido, que debe encarnarse en esa praxis aparentemente iluminada, ilustrada — luz solar de mediodía, que deslumbra pero que no ilumina-, que quiere, en el tiempo de la historia, calmar la inquietud radical que, repetimos, caracteriza a toda vida humana. En definitiva, liberar al ser humano de esa llamada «conciencia desventurada», que al no dejar que la vida se fije en lo conseguido, en lo logrado, por ser siempre aspiración de un «más», de una excelencia todavía-no-encontrada, sentida pero a distancia, no permite la paz; pero, sobre todo, no permite la identificación de ninguna forma política con paraíso humano alguno.

«Metafísica de la creación», voluntad y libertad configurándose autónomamente. Rechazo, no puede ser de otra manera, de todo «canon» por clásico que sea. Exigencia de una persona humana exenta, libre, fundándose a sí misma y conformando todo lo existe.

«¿De dónde procedía, pues, la violencia europea? Por lejos que dejemos vagar nuestra mirada, siempre nos encontramos con ella... Y la violencia en Europa no ha necesitado justificarse, porque su justificación estaba dada de antemano. Europa se había constituido en la violencia, en una violencia que abarcaba toda posible manifestación, en una violencia de raíz, de principio. La violencia estaba en todos los aspectos de su vida. ¿En dónde estriba el origen de la violencia europea? Hacer esta pregunta equivale a preguntarse por los orígenes de Europa, por su nacimiento. Y por la sustancia de la vida europea...Europa no hereda de Grecia sus dioses ya desacreditados y consumidos por la filosofía griega. Su Dios le viene de un pueblo semita; es, de todos los dioses, el Dios creador por excelencia. El que ha sacado al mundo de la nada.» ${ }^{10}$

Por eso, la moderna cultura europea es, según Zambrano, la manifestación del culto idolátrico al Dios Creador, «porque al adorar a este Dios de la creación y de la misericordia, se subraya lo primero. De las dos actividades de la Divinidad, la primera parecía atraer más que la segunda. ${ }^{11}$ El hombre europeo se glorifica por la creación. Por tanto, la violencia que reina en Europa viene de lejos, del culto idolátrico al Dios Creador, que supone el olvido de su misericordiosa ternura, porque no hay acto más violento que crear desde la nada, sin condición, y después no cuidar, no respetar, no amar lo que ha sido creado. El anhelo de ser imagen y semejanza de su Creador se sustituye por el anhelo de ocupar su lugar, de querer ser Dios Creador sin Dios Misericordia: creación sin condición y, por eso, dominio sin misericordia, sin atención a lo creado. Olvido del luminoso contenido de esa sabiduría que quiere mantener, y con razón, la

10 M. Zambrano, La agonía de Europa, Obras Completas II, p. 350.

11 Ibid., p. 351. 
vigencia de un «pecado original»: canon, mandamiento, precepto, límite para lo humano. Y la consecuencia, como indica Miguel García-Baró, se impone:

«No hay límite alguno para la transformación del mundo y de la sociedad, porque nada hay ni perfecto ni imperfecto; pero tampoco existe nada que le puede delimitar tajantemente como la legalidad natural y sea capaz de sofocar la acometida heroica del furor creativo o destructivo de la vida, de la conciencia, del hombre. Esta enseñanza, más vieja que Sócrates, es la propia de la sofística, como lo es actualmente de los movimientos postmodernos de reivindicación de ésta.» ${ }^{12}$

Porque «sólo desde la nada el hombre podrá crear como Dios, ya ni siquiera a "imagen y semejanza", sino igual a como Él lo hiciera. Es la terrible violencia del pensamiento que expresa la otra terrible violencia del existir.» ${ }^{13} \mathrm{Y}$, por eso

«la más grave enfermedad europea será la caricatura de su íntima esperanza, la que envuelve la traición a su utopismo revolucionario de resurrección. Enfermedad que, bajo la aparente energía, oculta la desgana, la fatiga de seguir viviendo en tensión, en la tensión idealista del habitante de dos mundos. La fatiga de este consubstancial idealismo puede llamarse pragmáticamente necesidad de "éxito' inmediato, de destruir el horizonte para que todo esté al alcance de la mano; embriaguez que haga olvidar la distancia insalvable entre las dos ciudades, la de Dios siempre en el horizonte, y la de la tierra, siempre en edificación, que anule también la diferencia entre los dos hombres, entre el hombre concreto y el siempre naciente "hombre nuevo". La anulación totalitaria de la distancia, de la distinción entre "el bien que quiero y el mal que hago". Barbarie monista, falsificada mística que suplanta a la permanente esperanza de resurrección y a la consustancial utopía creadora. Cansancio de la lucidez y del amor a lo imposible y abandono del saber más peculiar del hombre europeo: el saber vivir en el fracaso.» ${ }^{14}$

"Abandono del saber más peculiar... Saber vivir en el fracaso», conciencia desventurada, conciencia de un «más» siempre buscado y nunca alcanzado. Y, por eso, cansancio de la lucidez y del amor a lo imposible. Instalación en los éxitos efímeros alcanzados, ciertamente con esfuerzo, pero, también muy al alcance de la mano, de la manipulación humana, demasiado humana. Y nuevamente la sabiduría de D. Miguel. La situación cultural actual, que debe ser enfrentada con exigente responsabilidad ética, al estar dominada por la sola «razón instrumental» se caracteriza por no haber pensado detenidamente las consecuencias de entregar a las «Antonias Quijanas» las radicales inquietudes de los «Alonsos Quijanos», que siempre piden, por eso, «locos Quijotes», querer trasladar, para hacerse dignos del amor (Dulcinea), la bondad íntegra a la historia, o en palabras constantemente repetidas por la propuesta unamuniana, querer que el Reino de Dios se implante en la tierra ${ }^{15}$.

12 M. García-Baró, De estética y mística. Sígueme, Salamanca, 2007. p. 15.

13 M. Zambrano, La agonía de Europa, Obras Completas II, p. 360.

14 Ibíd., p. 390.

15 M. Zambrano, Unamuno, o.c., pp. 116-117. 
«Ya lo dice Unamuno y éste es el drama humano de la historia en España, su lucha y vencimiento ante lo doméstico: "Es tu sobrina, Don Quijote, es tu sobrina la que hoy reina y gobierna en tu España; es tu sobrina y no tu Sancho. Es la medrosica, casera y encogida Antonia Quijana, la que temía te diese por dar en poeta, "enfermedad incurable y pegadiza"; la que ayudó con tanto celo al cura y al barbero a quemar tus libros; la que te aconsejaba no te metieses en pendencias ni fuese por el mundo en busca de pan de trastrigo; la que se atrevió a asegurar en tus barbas que todo eso de los caballeros andantes era fábula y mentira, doncellesco atrevimiento que te obligó a exclamar: "Por el Dios que me sustenta que si no fueras mi sobrina derechamente como hija de mi misma hermana, que había de hacer un tal castigo en ti, por la blasfemia que has dicho, que sonara por todo el mundo"; es esta la "rapaza que apenas sabe menear doce palillos de randas" y se atrevía a poner lengua en las historias de los caballeros andantes y a censurarlas; es ésta la que maneja y zarandea y asendera como a unos dominguillos a los hijos de tu España. No es la Dulcinea del Toboso, no... es Antonia Quijana, la que apenas sabe menear doce palillos de randas y menea a los hombres de hoy en tu patria ${ }^{16}$

La inhibición de aquello que más caracteriza la índole propia de la vida humana —inhibición que siempre provocará resentimiento, odio y, sobre todo, la feroz envidia-, asendera los proyectos vitales del ser humano (¿es el drama de la historia de España o de toda la cultura occidental?). Por eso, vencer esta inhibición, volver a poner palabras adecuadas al ínsito anhelo de las «entrañas humanas» para ofrecer un proyecto de vida a la altura de la condición humana, será siempre la noble tarea que propiciada por Don Miguel, y continuada por la generación del '98, asumirá Zambrano como reto fundamental de su propuesta filosófica.

3. A LA BÚSQUEDa DE UNA «RAZÓN» MÁS AMPLIA QUE PERMITA VISLUMBRAR «LA VERDAD DE LA VIDA»

Se trataría, pues, de que la sabiduría filosófica asuma como tarea fundamental, filosofía primera, no la investigación sobre el ser, tampoco la investigación sobre las posibilidades del conocer, ni siquiera la investigación ética, tareas todas ellas necesarias, pero segundas, sino la investigación, sin prejuicios teóricos y sin opiniones infundadas, sobre el yo humano, sobre su intimidad más íntima. Pero dicha filosofía primera exige mucha delicadeza porque, según nuestra pensadora:

«Unamuno vive todavía dentro del ciclo del romanticismo y del idealismo, pues el idealismo alemán hizo del yo la realidad radical, transcendental por excelencia. Por su parte, el romanticismo literario permitió esta libertad hasta el exceso de hablar desde del yo. Los dos romanticismos, filosófico y

16 Ibíd., pp. 117-118. (cf. M. Unamuno, Vida de Don Quijote y Sancho, en Obras Completas, VII, Escelicer, Madrid, 1967, pp. 519-520). 
literario, parten de un supuesto común: el valor del individuo como tal, su carácter de unicidad; es como si hubiese llegado a ser creencia presupuesta la definición que Leibniz da de la "mónada" en que se refleja el universo. Cada individuo como una perspectiva infinita abierta sobre el mundo que le rodea y encuentra, por tanto, legítimo lanzarse a escribir como tal individuo, manifestar sus opiniones. El tener talento significa poseer esta reserva, tesoro, que el individuo lleva encadenado dentro de sí y que sólo precisa desplegar, y cuando más pulir, educar. El escritor, el intelectual ha sido posible como tipo humano sobre esta fe que ha parecido evidente, indiscutible.» ${ }^{17}$

Es decir, dicha filosofía primera no puede caer en la tiránica necesidad, afán irrenunciable, de hacer la propia historia sin el debido discernimiento. Porque esa historia que nace de la más profunda interioridad puede caer en la tentación de aceptar como testimonio sagrado (lo intocable: dogmatismo), que no santo (amor misericordioso: dialogo fraterno), todo lo que acontece en ella: el peligro de considerar cualquier contenido de experiencia interior como definitorio del propio ser. ¿Cuál de los contenidos que aparecen en la interioridad ha de ser escuchado? ¿Cómo obedecer (ob-audire) para descubrir el auténtico anhelo que define la vida humana? ¿Puede decirse arbitrariamente? Y ¿de dónde proceden dichos contenidos? ¿Tienen su origen solamente en la relación que el yo establece con su circunstancia? O ¿pueden encontrarse contenidos en el yo, que haciendo presente la alteridad, lo otro del yo, no procedan de la relación que el hombre establece con su circunstancia para hacer viable su vida? Y si estos contenidos existen y pueden ser adecuadamente fundados, ¿ son el resultado del despliegue evolutivo de la vida (origen biológico), o tienen que ser remitidos, en última instancia, a un principio originante no reducible a leyes biológicas?

El problema es grave: muchas «voces» parecen habitar en el seno del yo, y acallar esta ruidosa pluralidad exige un gran esfuerzo reflexivo para estar a la altura de lo humano.

«Uno de los prejuicios extremos de este tiempo de creencia en la riqueza última y radical del individuo es la pobreza de normas, de cauces de vida, de disciplinas interiores y exteriores, que los ha dejado en potencia de algo que sólo al ser exigido hubiera sido cumplido, pero que era su verdadera figura, su autenticidad. Pues no resulta evidente, ni mucho menos, que el ser auténtico de una persona consista en lo que buenamente alcance.... ${ }^{18}$

Y en Unamuno, Don Miguel, puede aprenderse, además, una grave advertencia para enfrentar el duro y exigente discernimiento requerido: ni tradicionalismo ni anarquismo pueden ofrecer los criterios de discernimiento para elaborar una propuesta adecuada. Conservar por conservar, destruir por destruir, son dos posiciones que engendran actitudes intelectuales perversas y opciones morales aviesas, porque impiden hacerse cargo de la verdad de la vida humana.

17 Ibid., p. 41

18 Ibid., p. 42. 
«Y es que, por mucho que se quiera, somos algo más que puro ímpetu de existir. Y la tragedia de la existencia, que es la de Don Miguel en todo su desgarramiento y plenitud, deja un resquicio, tiene que dejarlo para la objetividad. $\mathrm{Y}$ al fin, si no se puede vivir de la razón, tampoco es posible vivir sin ella.» ${ }^{19}$

Y tras el rechazo tanto del tradicionalismo como del anarquismo, conviene subrayar que tanto el positivismo histórico, que disuelve la historia en «hechos» perdiendo su sentido, como la fácil hermenéutica historicista, que olvida las exigentes condiciones de una adecuada teoría de la verdad, tampoco ofrecen propuestas adecuadas para hacerse cargo de la vida humana en el seno de la temporalidad. Porque para proponer una adecuada comprensión de la temporalidad humana es necesario describir al sujeto que abre sentido (temporalidad ontológica: verdad de la vida) en el devenir temporal (temporalidad óntica); el sujeto que es condición de posibilidad no del paso del tiempo, sino de la historia; en definitiva, atender al ser humano, pero no al ser humano en general desde el cual cualquier yo singular aparece como contingente; sino, y nos separamos de la abstracción moderna y de su yo formal, al ser humano de "carne y hueso", es decir, el ser humano que nace, crece, juega, trabaja, ama, envejece y muere, sobre todo, muere.

«La faena de hallarle un ser a las cosas fue empresa fácil si la vemos al lado de esta tremenda de encontrar el propio ser. Y éste es el camino de la tragedia. La obra de Unamuno está dentro del ámbito de la tragedia no por su pensamiento de Del sentimiento trágico de la vida, pues el pensamiento es siempre lo menos trágico, y en el capítulo central de su obra que él pretendió fuera su Evangelio, su máxima revelación, ese capítulo, "En el fondo del abismo", es el más objetivo y sereno, allí donde el personaje es capaz de mirar con mirada más tranquila, allí donde es capaz de encontrar las dificultades y hasta de subrayarlas. $»^{20}$

Si se acepta la radical singularidad del «hombre de carne y hueso», es necesario convenir, frente a toda la izquierda hegeliana y su materialismo abstracto, que la idea de especie, sumamente válida para un saber que intenta ser fiel a la metodología de la ciencia, nunca podrá ser aceptada por una buena antropología filosófica. El ser humano es mismidad y, por eso, cada ser humano es una especie. Cada ser humano es único, original e irrepetible. El concepto «especie», con independencia del debate hoy existente sobre su estatuto ontológico ${ }^{21}$, no solo no aclara, sino que esconde la índole propia de lo humano. La buena filosofía nunca podrá aceptar el reduccionismo metodológico al que se obliga la ciencia para alcanzar sus objetivos ${ }^{22}$ si quiere enfrentar el

\footnotetext{
19 Ibid., p.124.

$20 \quad$ Ibid., p. 97.

21 Cf. A. Marcos; M. Pérez Marcos, Meditación de la naturaleza humana. BAC, Madrid, 2018, pp. 235-245.

${ }_{22} \mathrm{Y}$ también consideramos insuficientes los reduccionismo epistemológicos y ontológicos, que ya no son científicos, sino filosóficos, para acceder a la entraña de lo humano. Aquí no podemos abrir esta discusión, pero sí creemos que debe ser apuntada.
} 
problema del yo único, original, irrepetible y mortal. Este rechazo, que nunca podrá ser excusa que impida el diálogo interdisciplinar, no sólo abre el espacio propio de la filosofía primera, sino, ante todo y sobre todo, la posibilidad de la fundamentación/defensa de la dignidad humana, que el amor a la sabiduría siempre asumió como encarnación ética de su quehacer reflexivo.

La técnica/ciencia/tecnología tienen valor humanizador pues buscan el dominio de la alteridad para hacer viable la vida. Logran que la ansiedad, engendrada por la incertidumbre que caracteriza el vivir, disminuya cuanto sea posible en la vida humana. El peligro de su proyecto humanizador es que, en su afán de dominio, no sepa escuchar las exigencias de la singularidad y, por eso, intente también su dominio, provocando la naturalización de la naturaleza humana, es decir, la reducción de lo humano a pura animalidad; o, más grave todavía, la consideración de lo humano a una cosa más entre las cosas.

Y el camino de la filosofía primera se va configurando. Si se acepta la necesidad de mantener la singularidad de cada vida humana, el problema se manifiesta con claridad y la propuesta de María Zambrano es muy consciente de él:

«Si se acepta que el hombre tiene la posibilidad de distintas versiones, cada una de ellas resultará siempre problemática. Si se abandona la creencia en la naturaleza humana de esencia permanente y universal, cada manera concreta de ser hombre adquiere el rango de lo problemático... Y lo más delicado y peligroso tal vez de todo ello, por ser previo y no enteramente visible, es este espacio vital (interioridad humana) donde la realidad, incluso la nuestra, se nos hace accesible... Espacio vital que se ha pedido a gritos sin lucidez alguna, pues claro es que no puede corresponder al espacio geográfico, en que un pueblo domina sobre los demás. Se trata de una transposición a términos sociales y políticos de algo más hondo, de ese espacio vital (interioridad) que al faltar produce la asfixia de toda vida humana... Lo que sucede, en verdad, es que la diversidad de revelaciones individuales muestra la falta de la revelación común que hace que el vivir sea convivir» ${ }^{23}$

«Revelación común», pretensión de sabiduría trascendental, «fundamento común», que la propuesta filosófica no puede perder. Porque es aquí donde debe injertarse toda biografía para, siendo fiel a su mismidad, poder abrir, generosamente, desde la vida personalmente vivida, nuevas posibilidades para todo ser humano, para su original, único e irrepetible caminar.

No puede olvidarse que lo primero que el ser humano forma en su trayecto vital es su dimensión social, es decir, la estructura (tendencias, hábitos, costumbres, normas, leyes...) que posibilita el trato con los demás. Pero esta «naturaleza civilizada» no implica, sin más, intimidad. Ésta exige creación y recreación propia, su «sustancia inalienable», que posibilita, como advierte Jesús Conill, que el ser humano camine hacia su plena personalidad.

23 M. Zambrano, Unamuno, o.c., pp. 67-68. 
«La intimidad liberadora invita, como hizo Goethe, a evadirse de "lo demás" y a "instalarse en sí mismo", logrando así "la liberación hacia sí mismo. Aunque no sepamos en qué consiste exactamente el sí mismo, el "ser sí mismo" se siente como una caricia deliciosa y liberadora (según Ortega recordando a Goethe), que nos hace disfrutar y que constituye la "Personalidad", la intimidad personal. No obstante, lo problemático de la intimidad es el fondo, porque el "sí mismo" en lo que cada cual es "en el fondo". Pero, ¿qué es lo que cada uno es y lo que cree en el fondo de sí mismo? No es fácil descubrirlo tras las sucesivas "capas geológicas" de los "falsos yos que me han colonizado", con las ideas recibidas, las preferencias que el entorno impone, los sentimientos por contagio... $»^{24}$

Lo que sí es cierto es que este "sí mismo», este "dentro», interior intimo meo, contra todo gnosticismo, no es, no puede ser si se aceptan todas las dimensiones del hombre de carne y hueso, cosa espiritual frente a lo corporal y, por eso, para acceder a él no basta, ya está afirmado en la apertura de la reflexión, la «mística del místico norteño». Se trata de

«Que el hombre vaya siendo otro, que las facetas inéditas de la hombría, las zonas no usadas por la humanidad, vayan apareciendo por obra de imprecisos acontecimientos, para que sobre esa nueva realidad no hecha presente hasta hoy se forje, se produzca, la intuición del nuevo proyecto de ser hombre, la imagen del hombre nuevo imponiendo su realidad a todos los caprichos de la mente, barriendo todo idealismo y toda imagen creada sobre los despojos de ayer. $»^{25}$

Y ante esos «imprecisos acontecimientos» que desnudan las seguridades de la vida, aparece con claridad el límite que caracteriza a la razón humana: el orden y la conexión de las ideas racionales desea aprehender definitivamente (totalidad) la exterioridad para alcanzar seguridad, un absoluto dominio sobre el devenir temporal. Pero cuando dicha razón se enfrenta con la vida humana, se ve obligada a encararse con el problema del acontecer histórico, y experimenta que la potencia de la exactitud matemática, del «método matemático», se quiebra. Y ante la imposibilidad de precisión brota la tentación que ya hemos nombrado: la reducción de la vida humana, o quizá de toda vida, a realidad natural, naturalización de toda vida para defender la validez de la razón. Entonces, la vida y, sobre todo, las vidas humanas quedarían sacrificadas en virtud de la defensa de la razón, que sólo acepta aquello que por sí misma, exenta de todo, puede encontrar.

Pues bien, si no se enfrenta adecuadamente esta trágica divergencia (Unamuno otra vez), acontece, según Zambrano, un falso camino de acceso a la intimidad - aunque algunos no quieran aceptarlo, porque los misticismos gozan de gran plausibilidad en la cultura actual-:

24 J. Conill, Intimidad corporal y persona humana. De Nietzsche a Ortega y Zubiri. Tecnos, Madrid, 2019, p. 61.

25 M. Zambrano, Los intelectuales en el drama de España, Obras completas I, o.c., p. 38. (el subrayado es mío) 
«...esta trágica divergencia puede dar origen a una actitud místicamente irracionalista, fenómeno del que existen abundantes muestras en el mundo occidental europeo. Actitud que bajo apariencias heroicas oculta una profunda falta de valor y un absoluto descreimiento en el porvenir del hombre y cuya última raíz sería la desesperación.» ${ }^{26}$

Por tanto, no se trata de renunciar a la razón, porque...

«...del largo pasado racionalista nos ha quedado la prueba de que la razón ha podido alcanzar resultados positivos. Se trataría, por tanto, de descubrir un nuevo uso de la razón, más complejo y delicado, que llevara en sí mismo su crítica constante, es decir, tendría que ir acompañado de la conciencia de la relatividad. El carácter atribuido al ser es lo que está realmente en crisis, y la cuestión sería encontrar un relativismo que no cayera en el escepticismo, un relativismo positivo. Quiere decir que la razón humana tiene que asimilarse al movimiento, el fluir mismo de la historia, y aunque parezca poco realizable, adquirir una estructura dinámica en sustitución de la estructura estática que ha mantenido hasta ahora. Acercar, en suma, el entendimiento a la vida, pero a la vida humana en su total integridad, para lo cual es menester una nueva y decisiva reforma del entendimiento humano o de la razón, que ponga a la razón a la altura histórica de los tiempos y al hombre en situación de entenderse a sí mismo. ${ }^{27}$

¿Qué exigencias impone a la razón este «relativismo positivo»? Se trata, siempre según Zambrano, de evitar dos extremos: el dogmatismo, el sistema cerrado y total, que siempre sacrifica la vida en el altar de la razón (la presencia de Unamuno y Ortega es evidente: crítica al racionalismo/idealismo); y el escepticismo, origen de toda desesperanza, que siempre sacrifica la verdad, o su posible búsqueda, en el altar de la espontaneidad vital (crítica a los excesos de los vitalismos fundados en una no precisa lectura de Nietzsche). Y así se establece un claro punto de partida, condición necesaria pero no suficiente, para propiciar el acceso a esa intimidad:

«Durante mucho tiempo — siglos — se ha creído que la inteligencia era de naturaleza inmutable y eterna; algo inalterable que pasaba por el mundo sin romperse ni mancharse. Pura, permanente e intemporal, no tenía propiamente historia. No cabía desentrañar lo que a la inteligencia le pasaba porque en realidad no podía pasarle nada, como nada le pasa a la luz que atraviesa cosas y sucesos, haciéndonoslos ver sin alterarse. La inteligencia era una forma pura que no participa de las conmociones de su objeto, ni tampoco de ninguna de las conmociones del hombre, por profundas que sean. Esta idea del hombre acerca de la razón se forja en Grecia y tiene tal fuerza de persistencia que se desaprovechó para corregirla hasta el gran drama cristiano, la revolución cristiana, cuyo destino era horadar la razón y lanzarla más allá del racionalismo griego. No aconteció al no ser aceptada y, por el contrario, el

26 Ibid., p. 79.

27 Ibíd., p. 80. 
racionalismo europeo moderno elevó a su máximo grado y a su mayor expresión esta idea de la razón, creyendo además en su poder absoluto.» ${ }^{28}$

La idea moderna de progreso nace, ciertamente, de las resistencias que la realidad, insumisa, ofrece al optimismo racionalista: se trataría de dominar racionalmente la naturaleza y de ordenar racionalmente la sociedad para que la vida humana alcance su plena libertad. Pero, ahora podemos saberlo, dicha idea contiene un análisis muy superficial del tiempo histórico, del tiempo humano. Palabras como avanzado, nuevo... son sinónimos de claridad, de bondad, de verdad; mientras que: anterior, viejo... aparecen como sinónimos de oscuridad e irracionalidad. Por eso - y conviene pensar con detenimiento en la situación cultural actual lo que nuestra pensadora afirma-,

«Era igualmente obvio que la inteligencia sin más era de por sí progresista y que no cabía una inteligencia reaccionaria. Tan obvio, que se ha descuidado por los intelectuales combatir sus brotes y escudriñar sus raíces. Inteligencia reaccionaria era simplemente falta de inteligencia y se suponía a los reaccionarios siempre pobremente dotados de este precioso instrumento. Una verdad, sin duda, resplandece en el fondo de esta concepción, y sólo le reprochamos a estos progresistas liberales su excesiva simplicidad y ligereza, su superficialidad al no tener en cuenta los subterfugios y disfraces de que el hombre es capaz y sobre todo y más gravemente el no distinguir entre la inteligencia como dote de un hombre concreto de carne y hueso y la inteligencia en su historia, en su desenvolvimiento a través de los sucesos más encontrados. ${ }^{29}$

El racionalismo/idealismo, la altísima imagen que forja de la razón, no permite ver con claridad esas necesidades y deseos humanos que siempre orientan a la misma razón hacia finalidades, a veces, enmascaradas. La filosofía moderna impide elaborar criterios de discernimiento para enfrentar ese más acá o más allá, en definitiva, ese fuera de la razón, dirigiéndola. Se impide, así, una verdadera crítica de la razón. El hombre, entonces, se evita a sí mismo, elude la averiguación sobre sus verdaderos deseos y necesidades, sobre su excelencia. El problema ha sido decidido, sin más, al considerar que la llamada razón progresista goza de absoluta inmunidad.

«Pero como esta pura existencia de ángeles del intelecto no podía anular la realidad diaria, se fue formando en el hombre una turbia conciencia. Esa conciencia de los adolescentes cuando se tropiezan, sin poderla todavía interpretar por inexperiencia, con la riqueza contradictoria de la vida... La adolescencia es el choque del idealismo infantil con la riqueza dispar de la realidad; se sale de ella por sucesivas experiencias que nos van haciendo tomar posesión del mundo y de los propios tesoros de nuestra individualidad... Para tomar posesión de los tesoros de la propia personalidad es menester que las situaciones de la vida nos hagan recurrir a ellos; al necesitar de estos recursos los ponemos al descubierto y nuestra vida se va equilibrando.» ${ }^{30}$

28 Ibíd., p. 29 (el subrayado es mío).

29 Ibid., p. 30.

$30 \quad$ Ibid., p. 32. 
«Posesión de los tesoros de la propia personalidad», esta es la responsabilidad ética que toda verdadera reforma del entendimiento, reflexión epistemológica, tiene que asumir o, al menos, no impedir, para que la vida humana no quede definida por una perpetua adolescencia: odio al presente, desesperación; odio a la vida justificado por la aparente perfección de los ideales fraguados por la sola y pura razón, siempre progresista; y, por eso, o restauración de pasados finiquitados o proyección de falaces futuros imposibilitando la verdadera maduración vital.

Pues bien, para sacar a la razón de esa «adolescencia» que no quiere contar con principio de realidad alguno, María Zambrano, siguiendo las insinuaciones de sus grandes maestros, nos ofrece una arriesgada propuesta: la razón sólo estará al servicio de la verdad de la vida humana, no solo de su realidad, cuando sepa acoger, hospedar, escuchar, sin intentar dominar, la experiencia de vida humana, experiencia antropológica, que se revela en la creación poética.

«Constituir el más fecundo saber de nuestros días, aquel que advierta al hombre, que le guíe y sobre todo: que le enamore y o le reenamore... (Porque) el nuevo saber fecundo sólo lo será si brota de unas entrañas enamoradas. (Porque) sólo así será todo lo que el saber tiene que ser: apaciguamiento y afán, satisfacción, confianza y comunicación efectiva de una verdad que nos haga de nuevo comunes, participantes; iguales y hermanos. Sólo así el mundo será habitable. La Filosofía ha dado paso a la revelación de la vida y con ella a la historia, la historia llama a la poesía. Y así este saber será poético, filosófico e histórico. Estará de nuevo sumergido en la vida y quién sabe si haciéndonos posible liberarnos de ella.» ${ }^{31}$

Es decir, poesía e historia, anuladas por el racionalismo moderno, reaparecen en el estricto quehacer crítico de la filosofía. La poesía, que expresa aquello que la vida humana siente, necesita de la sabiduría filosófica para entender el por qué de esta vida sentimental. Y la historia no quedará reducida a la narración de hechos, porque la filosofía, sumergiéndose en ella, revelará la «intrahistoria», la «historia esencial», lo buscado desde siempre por el ser humano — verdad que personaliza y hermana, verdad trascendental- desde diferentes proyectos, pero respondiendo siempre a una misma vida sentimental: deseo metafísico, presencia de lo eterno, lo siempre presente acompañando la vida humana, en la temporalidad.

La poesía se atreve a proponer, defensa acompañada de profunda humildad, que los diferentes proyectos del ser humano, sus búsquedas, son determinadas por un sentimiento fundamental: «en el principio era el Logos (eterno)... Sí, pero el logos se hizo carne y habitó entre nosotros, lleno de gracia y verdad ${ }^{32}$. Verdad encarnada, gratuitamente donada. Verdad en la vida humana, anterior a toda reflexión, decisión, quehacer o poder y determinando todos ellos. Verdad que, por eso, explica todos los caminos de búsqueda. Verdad que, si es adecuadamente desvelada, conllevará una exigencia de escucha, obediencia (ob-audire), para la buena filosofía. Verdad que se expresa como «voz» que no obliga, eso viene después, pero que «llama» a responder al ser único, original e

31 M. Zambrano, Pensamiento y poesía en la vida española, Obras Completas, I, o.c., p. 568.

32 M. Zambrano, Filosofía y poesía, o.c., p. 687 
irrepetible que cada ser humano es. Obediencia que implicará precisión en su descripción, no pretensión de dominio; actitud teórica respetuosa con lo dado, no posesiva, iluminando el difícil camino de la libertad.

Ahora ya sabemos un poco más de ese «sí mismo»: espacio íntimo que los acontecimientos que desnudan la vida (corporeidad) nos descubre, donde se siente, vida sentimental, un anhelo que obliga a la búsqueda propia, a la configuración del propio proyecto personal, y, por eso, proyectos humanos plurales desde un sentir común.

«¿No será posible que algún día afortunado la poesía recoja todo lo que la filosofía sabe, todo lo que aprendió en su alejamiento y duda (nacimiento del sujeto: autonomía), para fijar lúcidamente y para todos su sueño?» ${ }^{33}$

Y la advertencia machadiana empieza a resonar con toda su fuerza vital:

«Dice la Razón: Busquemos la verdad.

Y el corazón: Vanidad. La razón ya la tenemos.

La razón: ¡Ay, quién alcanza la verdad!

El corazón: Vanidad. La verdad es la esperanza.

Dice la razón: Tú mientes.

Y contesta el corazón: quien miente eres tú, razón, que dices lo que no sientes.

La razón: Jamás podremos entendernos, corazón. El corazón: Lo veremos.» ${ }^{34}$

4. La poesía pensada por Antonio Machado: luZ Para la PROPUESTa buscada por MARÍA ZaMBRANO

La advertencia es clara y rotunda. Zambrano no quiere que su propuesta sea asimilada ni a misticismos irracionalistas ni a esteticismos emotivistas. Por eso, es necesario, exigencia ética, pensar con la debida parsimonia la verdadera experiencia antropológica que se hace presente en la creación poética.

Y encuentra en las propuestas de Machado caminos de iluminación ${ }^{35}$.

33 Ibid., p. 758.

34 A. Machado: Poesías completas, CXXXVII, VII, pp. 585-586 (citaremos a Machado siempre por la edición crítica de Oreste Macrí, Espasa Calpe, Madrid, 1989).

35 Dejándonos como invitación al estudio y a la admiración del poeta español estos dos textos:

«Entre todos los poetas que en su casi totalidad han permanecido fieles a su poesía, que se han mantenido en pie, ninguna voz que tanta compañía nos preste, que mayor seguridad íntima nos dé, que la del poeta Antonio Machado.» (Los intelectuales en el drama de España, Obras completas, I, p. 186). «Si algún día alguien quisiera averiguar la profunda gestación de nuestra historia más última, tal vez tenga que acudir a esta poesía como a aquello en que más cristalinamente se aparece.... Testimonio de nuestro suceso... La poesía hoy nos acompaña, justo es proclamarlo, y con tanta mayor imparcialidad por no ser quien esto afirma y siente de la estirpe de los poetas... La voz poética de Antonio Machado canta y cuenta de la vida más verdadera y de las verdades más ciertas, universales y privadísimas al 
Nuestra pensadora escribirá cuatro textos sobre él: La Guerra, de Antonio Machado, publicado en Hora de España, diciembre de 1937, que será incluido posteriormente en Los intelectuales en el drama de España; Antonio Machado y Unamuno, precursores de Heidegger, publicado en Sur (Buenos Aires), marzo de 1938, incluido también en Los intelectuales en el drama de España ${ }^{36}$; Antonio Machado, un pensador (apuntes), publicado en Cuadernos para el diálogo, noviembre de 1975; Palabras paternales, Diario 16, febrero de 1989, incluido en Las palabras de Regreso, síntesis breve de La Guerra, de Antonio Machado ${ }^{37}$.

La razón filosófica moderna buscando responder a la inquietud, deseo de «más», que caracteriza la vida humana se ha defendido, según Zambrano, de la angustia, engendrada por la posibilidad de que dicha inquietud no pueda ser respondida, colmada, proponiendo sistemas cerrados, dogmáticos. Porque la respuesta a tal inquietud debe ser totalmente sabida y realizada para que acontezca la reconciliación del hombre consigo mismo, con la naturaleza y con los demás para superar la «conciencia desventurada». El sistema es la forma de la angustia y la forma del poder. La configuración de una razón/voluntad obstinada en aplacar la inquietud humana: no saber vivir en el fracaso.

La poesía, sin embargo, no puede verterse en la forma del sistema, porque no puede quedar cerrada. El día en que quedase clausurada, sería el día final de la creación humano, que gracias a la poesía (imaginación), sigue su curso. Pero en la poesía también hay angustia: la que proviene de la obediencia a un sentir radical que levanta la vida humana por encima de sí misma, que la lanza y la exige ser más que sí misma. Ahora bien, en la angustia del poeta no hay amenaza alguna, ni deseo de poder, sino "santo temor», delicadeza extrema para que su acción creativa exprese adecuadamente la «santa presencia» de la inquietud no suprimible por modo alguno de razón en la intimidad humana.

«Y como triunfa Sócrates de la sofística protagórica, alumbrando el camino que conduce a la idea, a una obligada comunión intelectiva entre los hombres, triunfa Cristo de una sofística erótica que fatiga las almas del mundo pagano, descubriendo otra suerte de universalidad: la del amor. Ellos son los dos grandes maestros de la dialéctica, que saben preguntar y aguardar las

par de toda vida. ¿Qué sería de nosotros, de todo hombre, si no supiésemos hoy y no nos lo supiesen recordar el saber último que con sencillez de agua nos susurran al oído las palabras poéticas de Machado? Y aunque en última instancia, todo hombre, toda hombría en plenitud sepa de esas cosas, es necesaria siempre su formulación poética, porque en la conciencia de un poeta verdadero adquieren claridad y exactitud máxima... Palabras paternales son las de Machado, en que se vierte el saber amargo y a la vez consolador de los padres, y que con ser a veces de honda melancolía, nos dan seguridad al darnos certidumbre. Poeta, poeta antiguo y de hoy; poeta de un pueblo entero al que enteramente acompaña» (Ibíb, p. 187).

36 Este texto es una cita literal de las dos partes centrales de «Miscelánea apócrifa. Notas sobre Juan de Mairena» que Machado había escrito en enero de 1938 para Hora de España (cf. para más información: A. Bundgard, Más allá de la filosofía. Sobre el pensamiento filosóficomístico de María Zambrano, Trotta, Madrid, 2009, p. 115)

37 cf. también para más información: M. Gómez Blesa, La razón mediadora. Filosofía y piedad en María Zambrano. Ed. Gran Vía, Burgos, 2008, pp. 131-132 
respuestas. No son dos charlatanes ni dos pedantes. Charlatán y pedante es sólo quien habla y ni siquiera se escucha a sí mismo...» ${ }^{38}$

Y, aunque las referencias explícitas a la obra del poeta español no son frecuentes en nuestra pensadora, su presencia iluminadora es clara porque:

«Poesía es, sí, lucha con la carne, trato y comercio con ella, que desde el pecado - "la locura del cuerpo" - lleva a la Caridad. Caridad, amor a la carne propia y a la ajena... Porque al pecado de la carne sigue la gracia de la carne: la caridad.» ${ }^{39}$

Otra vez su posición anti-gnóstica y, por eso, la necesidad constante de luchar críticamente contra su tentación. Porque la poesía, por caminos distintos a la razón, también busca su defensa, su escapatoria. Si la razón se defiende con el sistema; la poesía busca defensa en el "sueño de la inocencia» ${ }^{40}$. Sueño anterior a la pubertad, y, por eso, anterior a la lucha por la libertad. Sueño que invita a sumergirse, diluirse en un «sagrado origen» cuando, precisamente, son sentidas las exigencias de la libertad, la responsabilidad que siempre acompaña a la decisión. "Sagrado origen», «lecho materno», que invita a quedarse a resguardo del riesgo de decidir.

«Y queda la poesía ligada a su sueño primero por la melancolía, melancolía que hace volver en su busca, para precisarlo, para realizarlo. La poesía busca realizar la inocencia, transformarla en vida y conciencia: en palabra, en eternidad.» ${ }^{41}$

Se muestra una nueva alternativa, un sorprendente o lo uno...o lo otro: o el «sueño nutricio» como disolución en el «sagrado origen», que no quiere ni enfrenta el riesgo de la libertad (el teólogo lo llamaría iluminismo; el filósofo, misticismo irracional); o el "poder de la voluntad» que no quiere, ni enfrenta la tarea de la escucha obediencial a la inquietud sentida en la intimidad, porque no quiere nada que pueda medir el cumplimiento de cualquier sueño de realización (el teólogo lo llamaría pelagianismo; el filósofo, proyecto de dominio de la totalidad). Surge, así, la pregunta que dirige todo el esfuerzo de la propuesta zambraniana:

«¿No será posible que algún día afortunado la poesía recoja todo lo que la filosofía sabe, todo lo que aprendió en su alejamiento y duda (nacimiento del sujeto: autonomía), para fijar lúcidamente, y para todos, su sueño?» ${ }^{42}$

Por eso, el deber que tiene la poesía de presentar con claridad su pretensión de verdad.

«Una de las cuestiones que más falta haría aclarar y poner de manifiesto es la diferente manera de ser poeta o las diferentes formas de poesía. No cabe con mínima honestidad intelectual abarcar lo mismo a fenómenos y sucesos

38 A. Machado, o.c., p. 1969.

39 M. Zambrano, Filosofía y poesía, o.c., 697.

$40 \quad$ Ibid., p. 753.

$41 \quad$ Ibid., p. 756.

42 Ibid., p. 758. 
tan desemejantes como el de Verlaine y Dante, por ejemplo. Aunque a todos abarque la unidad de la poesía, sin duda son varias las especies de ella, que hacen distinta la situación del poeta con respecto a su propia poesía y distinta la función histórica de la misma poesía. ${ }^{43}$

Y, también, por eso, la necesidad de dejarse guiar por la sabiduría machadiana.

«Pensamientos de un poeta que en Antonio Machado forma ya además un volumen casi parejo en extensión al de su poesía; Juan Mairena crece al lado de Antonio Machado. Quiere esto decir y lo dice, además, por la naturalidad de su prosa, y por la exactitud del concepto, que no se trata de un poeta que accidentalmente piensa. Y es el mismo quien nos lo dice: “Todo poeta —dice Juan Mairena- supone una metafísica; acaso cada poema debe tener la suya -implícita, claro está, nunca explícita-, y el poeta tiene el deber de exponerla por separado, en conceptos claros. La posibilidad de hacerlo distingue al verdadero poeta del mero señorito que compone versos". ${ }^{44}$

Pues bien, la forma más clara de acceder a la manera de ser poeta de Machado es recorrer - aquí no podremos hacerlo con detenimiento ${ }^{45}$ - su crítica a los modos de hacer poesía: 1) el culteranismo y el conceptismo (barroco español y Góngora; 2) el simbolismo (Verlaine; Mallarmé; Rimbaud); 3) el esteticismo poético o el arte por el arte (Gautier; Valéry; Huidobro).

Machado realiza una dura crítica al barroco español por su gran pobreza de intuición; por su culto a lo artificioso y desdeño de lo natural; por la carencia de temporalidad; por su culto a lo difícil y artificial e ignorancia de las dificultades reales; culto a la expresión indirecta, perifrástica, como si ella tuviera por sí misma valor estético; carencia de gracia; y culto supersticioso a lo aristocrático ${ }^{46}$. Para concluir que

«Culteranismo y conceptismo son, pues, para Mairena dos expresiones de una misma oquedad y cuya concomitancia se explica por un creciente empobrecimiento del alma española. La misma inopia de intuiciones que, incapaz de elevarse a las ideas, lleva al pensamiento conceptista, y de éste a la pura agudeza verbal, crea la metáfora culterana, no menos conceptual que el concepto conceptista, la seca y árida tropología gongorina, arduo trasiego de imágenes genéricas, en el fondo puras definiciones, a un ejercicio de mera lógica, que sólo una crítica inepta o un gusto depravado puede confundir con la poesía... en suma, Mairena no se chupa el dedo en su análisis del barroco literario español. Más adelante añade —en previsión de fáciles objecionesque él no ignora cómo en toda época, de apogeo o decadencia, ascendente o declinante, lo que se produce es lo único que puede producirse, y que aun las

43 M. Zambrano, Los intelectuales en el drama de España, o.c., pp. 186-187.

44 M. Zambrano, Senderos, Anthropos, Barcelona, 1989, p. 64. (Cf. para la cita A MachaDo, o.c., p. 706; cf. tyambién p. 1259)..

45 Permítame el lector remitirle a mi libro para más información: A. SÁnchez Orantos, La poesía que piensa. A la búsqueda de Dios con María Zambrano. U.P. Comillas, Madrid, 2017, pp. 45-175.

46 A. Machado, o.c., pp. 701-705 
más patentes perversiones del gusto, cuando son realmente actuales, tendrán siempre una sutil abogacía que defiende sus mayores desatinos ${ }^{47}$

Con independencia de la aceptación de esta crítica literaria - porque lo que se produce es lo único que puede producirse-, Machado quiere llevarnos a un convencimiento: culteranismo y conceptismo nos ofrecen una poesía que se dirige más al entendimiento que al corazón. Intelectualización de la belleza, pura oquedad que nunca podrá ser considerada verdadera poesía.

«Todo el encanto del soneto de Calderón — si alguno tiene- estriba en su corrección silogística. La poesía aquí no canta, razona, discurre en torno a unas cuantas definiciones. Es — como casi todo nuestro barroco literarioescolástica rezagada.» ${ }^{48}$

Y la poesía sólo será tal si encarna hondos estados de conciencia que desvelan la dimensión efectiva y emocional de la persona en contacto con la alteridad. La creación poética debe remitir la actividad intelectiva (yo) a la realidad (otredad) desde la vivencia (experiencia) presente en la subjetividad (interioridad). Es decir, el proceso de desubjetivación, que es lo propio de la ciencia, no debe reproducirse en la creación poética.

«Tiempo y espacio son dos instrumentos de la objetividad. ¿En qué sentido? Entendemos por objetividad los puntos de coincidencia del pensar individual (el múltiple pensar individual) que forman el pensar genérico, la racionalidad. La objetividad supone una constante desubjetivación, porque las conciencias individuales no pueden coincidir en el ser, esencialmente vario, sino en el no ser. Llamamos no ser al mundo de las formas, de los límites, de las ideas genéricas y a los conceptos vaciados de su núcleo intuitivo, al mundo cuantitativo, limpio de toda cualidad. ${ }^{49}$

La creación poética, es la insistencia de Machado, tiene que estar al servicio de la vida. La lógica eleática, al anular la subjetividad y al pensar lo existente fuera del tiempo, nunca podrá acceder a las entrañas de la vida. Y, por eso, las palabras de Mairena, que resonarán con fuerza en la propuesta de Zambrano:

«Algún día - habla Mairena a sus alumnos- se trocarán los papeles entre los poetas y los filósofos. Los poetas cantarán su asombro por las grandes hazañas metafísicas, por la mayor de todas, muy especialmente, que piensa el ser fuera del tiempo, la esencia separada de la existencia, como si dijéramos, el pez vivo y en seco, y el agua de los ríos como una ilusión de los peces. Y adornarán sus liras con guirnaldas para cantar estos viejos milagros del pensamiento humano. Los filósofos, en cambio, irán poco a poco enlutando sus violas para pensar, como los poetas, en el fugit irreparabile tempus. Y por este declive romántico llegarán a una metafísica existencialista, fundamentada en el tiempo; algo, en verdad más poemático que filosófico. Porque será filósofo quien nos hable de angustia, la angustia esencialmente poética del ser junto a la nada,

\footnotetext{
$47 \quad$ Ibid.

48 Ibid., p. 1180.

49 Ibid.
} 
y el poeta quien nos parezca ebrio de luz, borracho de los viejos superlativos eleáticos. Y estarán frente a frente poeta y filósofo — nunca hostiles- y trabajando cada uno en lo que el otro deja.» ${ }^{50}$ "Abel Martín tiene — no obstante- una profunda admiración por la lógica de la identidad que, precisamente por no ser lógica de lo real, le parece una creación milagrosa de la mente humana... pero muy lejos está... de creer en el valor pragmático de la lógica intemporal. La forma lógica del pensamiento es aquello que no puede estar jamás al servicio de la vida. Su inutilidad, en sentido vital, hace de ella el gran problema de la filosofía del porvenir. Abel Martín no piensa que sea la utilidad el valor supremo, sino, sencillamente, uno de los valores humanos. Lo inútil, en cambio, no es por sí mismo valioso... Pero tampoco hemos de sorprendernos si encontráramos en ello otro valor de más alta categoría que el de la utilidad.» ${ }^{51}$

Se trata de que la palabra humana pueda acceder a la verdad de la vida y, para ello, tiene que situarse en el interior de la subjetividad. Ahora bien, este mirar al interior tiene que evitar el riesgo, es el segundo modo de hacer poesía, del simbolismo ${ }^{52}$. Su premisa fundamental, reacción al naturalismo parnasiano, es que la naturaleza debe ser pensada como símbolo puro, de tal manera que permita el acceso a la emoción reprimida, espacio psíquico que olvida la cultura positivista. Para Machado, tanto el conceptismo - por exceso de razón/idea-, como el simbolismo - por exceso de voluntad/sensibilidad- encierran al sujeto en sí mismo, narcisismo, impidiendo la trascendencia de la vida.

«Una lírica intelectual me parece tan absurda como una geometría sentimental o un álgebra emotiva. Tal vez sea ésta la hazaña de los epígonos del simbolismo francés. Ya Mallarmé llevaba dentro el negro catedrático capaz de intentarla. Pero este camino no lleva a ninguna parte..$^{53}$

Se exige, por tanto, superar estos dos modos de poesía, porque «para pensar es preciso evitar dos escollos: lo visto y lo soñado.» ${ }^{54} \mathrm{Y}$, además, porque la oposición entre objetividad y subjetividad, conceptismo y simbolismo, aceptada como irresoluble, abrirá siempre el camino del esteticismo poético o el arte por el arte, el tercer modo de hacer poesía ${ }^{55}$. La crítica de Machado desde su deseo de poner la poesía al servicio de la vida se manifiesta con rotundidad:

«Porque el poeta no sacará nunca la poesía de la poesía misma. Crear es sacar una cosa de otra, y la materia sobre la cual se opera no puede ser la obra misma. Así, una abeja consagrada a la miel —y no a las flores— será más bien

\footnotetext{
50 A. MACHADO, o.c., p. 2050.

51 Ibíd., 681.

52 Movimiento poético que surge en Francia hacia el 1886. En este año publica El manifiesto simbolista Jean Moréas (1856-1910). Mallarmé (1842-1898), Rimbaud (1854-1891) y Verlain (1844-1896) serán sus máximos representantes.

53 A. MaCHADO, O.c., p. 710.

$54 \quad$ Ibíd., p.1250.

55 Es la propuesta de Paul Valéry (1871-1945), que tanto interés despertó en los poetas y literatos españoles y que se encarna, de forma radical, en el creacionismo de Vicente Huidobro (1893-1948), con su lema: «la verdad artística empieza allí donde termina la verdad de la vida»
} 
un zángano, y el hombre consagrado a la poesía y no a las mil realidades de su vida será el más grave enemigo de las musas... Por lo demás, erigir el arte, en fin, no es ennoblecerlo, sino degradarlo. Ni el reino de los fines, ni el reino de Dios son de este mundo. El arte podrá ser, cuando más, una escalera para llegar a Dios; pero una escalera será siempre un medio para subir; si pretendemos divinizarla, caeremos en idolatría, en fetichismo, en superstición. ${ }^{56}$ «A mi entender, la poesía ha sido siempre creacionismo, y jamás otra cosa; pero no creacionismo ex nihilo. Aunque bien está que el poeta pretenda obrar el milagro de la pura originalidad. ${ }^{57}$

La pretensión de la creación poética no podrá ser nunca pura invención, como si el poeta fuera un pequeño dios. La autorreferencialidad del poema es para Machado degradación de la poesía. El juicio existencial tiene que ser siempre el presupuesto del acto poético. Y Zambrano, asume con humildad, sus «palabras paternales». Es la nombrada "Metafísica de la Creación» y la poesía no puede estar al servicio de la embriaguez humana:

«En la embriaguez el hombre duerme, ha cesado perezosamente en su desvelo y ya no se afana en su esperanza racional. No sólo no se conforma con las sombras de la pared cavernaria, sino que sobrepasando su condena, crea sombras nuevas y llega hasta hablar de ellas y con ellas. Traiciona a la razón usando su vehículo: la palabra, para dejar que por ella hablen las sombras, para hacer de ella la forma de delirio. El poeta no quiere salvarse; vive en la condenación y todavía más, la extiende, la ensancha, la ahonda. La poesía es realmente, el infierno. El infierno, que es —como siglos más tarde un poeta platónico dijera- "el lugar donde no se espera”, es también el lugar de la poesía, porque la poesía es lo único rebelde ante la esperanza de la razón. La poesía es embriaguez y sólo se embriaga el que está desesperado y no quiere dejar de estarlo. El que hace de la desesperación su forma de ser, su existencia.» ${ }^{58}$

Los resultados del camino crítico recorrido son resumidos con claridad por el mismo Machado:

«Sólo en momentos perezosos puede un poeta dedicarse a interpretar los sueños y a rebuscar en ellos elementos que utilizar en sus poemas. La oniroscopia no ha producido hasta la fecha nada importante. Los poemas de nuestra vigilia, aun los menos logrados, son más originales y más bellos y, a las veces, más disparatados que los de nuestros sueños. Os lo dice quien pasó muchos años de su vida pensando lo contrario. Pero de sabios es mudar el consejo. Hay que tener los ojos muy abiertos para ver las cosas como son; aun más abiertos para verlas otras de lo que son; más abiertos todavía para verlas mejores de lo que son. Yo os aconsejo la misión vigilante, porque vuestra misión es ver e imaginar despiertos, y que no pidáis al sueño sino reposo... El pensamiento poético, que quiere ser creador no realiza ecuaciones, sino diferencias esenciales, irreductibles; sólo el contacto con lo otro, real o aparente, puede ser fecundo. Al pensamiento lógico o matemático, que es pensamiento

56 Ibíd., o.c., pp. 1550-1552.

57 Ibid., o.c., p. 1617.

58 M. Zambrano, Filosofía y poesía, o.c., p. 702. 
homogeneizador, a última hora pensar de la nada, se opone el pensamiento poético, esencialmente heterogeneizador. Perdonadme estos terminajos de formación erudita, porque en algo se ha de conocer que estamos en clase, y porque no hay cátedra sin un poco de pedantería.» ${ }^{59}$

Anhelo de realidad, de verdad, de vigilia... Mística poética de ojos abiertos y bien abiertos... pero ¿cómo encontrar camino (método) para responder a ese anhelo, que es, ante todo y sobre todo, anhelo de alteridad, Bien y Amor? Y Zambrano sigue aprendiendo:

«El pensamiento científico, descualificador, desubjetivador, anula la heterogeneidad del ser, es decir, la realidad inmediata, sensible, que el poeta ama y de la que no puede desprenderse. El pensar poético, dice Machado, se da "entre realidades", no entre sombras; entre intuiciones, no entre conceptos. El concepto se obtiene a fuerza de negaciones, y el "poeta no renuncia a nada ni prende degradar ninguna apariencia".. ${ }^{60}$

\section{Pero ¿cómo dar forma a esa lógica poética? Porque}

«Para comprender claramente el pensamiento de Martín en su lírica, donde se contiene su manifestación integral, es preciso tener en cuenta que el poeta pretende, según declaración propia, haber creado una forma lógica nueva, en la cual todo razonamiento debe adoptar la manera fluida de la intuición.» ${ }^{61}$

Recojamos lo conseguido. El Hay natural impone a la vida humana la exigente necesidad de dominar el entorno para hacerse viable. En este continuo trabajo, que nunca puede ser abandonado, el ser humano se vuelca de tal manera en la exterioridad que corre el riesgo de olvidar su propia interioridad: perder su intimidad. Por imprevisibles acontecimientos que desnudan las seguridades conseguidas, el ser humano empezará a vislumbrar la necesidad de cuidar de sí mismo, de atender a su intimidad. Ahora bien, el exceso de cuidado de esta intimidad, el puro centrarse en ella, abocará al encerramiento del hombre en sí mismo, narcisismo, pérdida de la relación con la realidad y con los demás. Es el problema del sofista que con tanta brillantez enfrenta Sócrates/Platón.

«La fe platónica en las ideas trascendentales salvó a Grecia del solus ipse en que la hubiera encerrado la sofística. La razón es pensamiento genérico. Quien razona afirma la existencia de un prójimo, la necesidad del diálogo, la posible comunión mental entre los hombres... Sin la absoluta trascendencia de las ideas, iguales para todos, intuibles e indeformables por el pensamiento individual, la razón, como estructura común a una pluralidad de espíritus, no existiría, no tendría razón de existir. Dejemos a los filósofos que discutan el verdadero sentido del pensamiento platónico. Para nosotros lo esencial del

59 A. MACHADO, O.c., p. 1963.

60 M. Zambrano, Los intelectuales en el drama de España, o.c., p. 193.

61 A. Machado, o.c., p. 680. 
platonismo es una fe en la realidad metafísica de la idea, que los siglos no han logrado destruir. ${ }^{62}$

La grandeza de tal propuesta es evidente. El ser humano queda salvado de la exterioridad desde las Inmutables Ideas y, éstas, se constituyen, salvando así el narcisismo, en fundamento de toda posible vida en comunidad. La convivencia humana queda asegurada por la obediencia que debe prestar toda subjetividad a esa trascendencia intemporal. Obediencia que, si se admite sin más, obligará siempre a dirigir la mirada a un más allá que imposibilita la vida en la historia real, la vida encarnada.

Por eso, la obra de Sócrates/Platón nunca debería ser considerada como meta final, sino como camino (método) que invita a proseguir la búsqueda de la verdad como voz que llama a la vida buena.

«Bergson calumnia a Platón. Pero invocar la tradición helénica, volviendo la espalda al pensar teórico, es un contrasentido. Hemos lamentado, con amarga insistencia, el no poder penetrar en las cosas. Pero, las cosas no son sino, precisamente, por este milagro de inhibición del sujeto consciente, que está siempre fuera de las cosas... La anulación de lo inmediato psíquico, para crear la realidad de segundo término, el objeto intelectual, tiene su grandeza y su encanto. Algún día lo cantarán los poetas... La intuición bergsoniana, derivada del instinto, no será nunca instrumento de libertad, por ella seríamos esclavos de la corriente vital. Sólo la inteligencia teórica es un principio de libertad (de libertad y dominio). Libertad y dominio son dos caras de la misma moneda. Sólo conociendo intelectualmente, creando el objeto, se afirma la independencia del sujeto, el que nunca es cosa sino vidente de la cosa. ${ }^{63}$

Es decir, salvado el peligro de identificación del ser humano con cualquier realidad natural: nunca cosa sino vidente de la cosa, surge con máxima exigencia el problema de la alteridad y, sobre todo, el problema de la alteridad humana. Porque no basta la razón para crear convivencia humana.

«Grande hazaña fue el platonismo — sigue hablando Mairena- pero no suficiente para curar la soledad del hombre. Quien dialoga ciertamente, afirma a su vecino, al otro yo; todo manejo de razones — verdades o supuestosimplica convención entre sujetos o visión común de un objeto ideal. Pero no basta la razón, el invento socrático para crear la convivencia humana; ésta precisa también la comunión cordial, una convergencia de corazones en un mismo objeto de amor» ${ }^{64}$ «Después que Platón, en sus diálogos inmortales, descubre la razón, el pensamiento genérico, las ideas que todos hemos de pensar conducidos por la lógica, merced a la común estructura de nuestro entendimiento, el diálogo sigue su camino» ${ }^{65}$. Porque

«Han tomado sus medidas

Sócrates y el Cristo ya:

62 Ibid., o.c., pp. 1967-1968.

63 Ibíd., pp. 1193-1194.

64 Ibíd., p. 1968.

65 Ibid., p. 2371. 


\author{
El corazón y la mente \\ un mismo radio tendrán.» ${ }^{66}$
}

La convivencia humana, proyecto de amor, exige, es la profunda exigencia de la lógica poética, insertar la palabra en el tiempo, encarnación, para abocar razonadamente no a ideas inmutables, sino, si es posible, a los universales del sentimiento ${ }^{67}$, donde puedan confluir voluntad y razón, razones de amor, que, si son obedecidas, abrirán un espacio, Persona y Democracia, para una auténtica vida humana.

«...la conciencia - dice Abel Martín-, como reflexión o pretenso conocer del conocer, sería sin el amor o impulso hacia lo otro, el anzuelo en constante espera de pescarse a sí mismo. Mas la conciencia existe, como actividad reflexiva, porque vuelve sobre sí misma, agotado su impulso por alcanzar el objeto trascendente. Entonces reconoce su limitación y se ve a sí misma como pretensión erótica, impulso hacia lo otro inasequible. Su reflexión es más aparente que real, porque, en verdad, no vuelve sobre sí misma para captarse como pura actividad consciente, sino sobre la corriente erótica que brota con ella de las mismas entrañas del ser. Descubre el amor como su propia impureza, digámoslo así, como su otro inmanente y se le revela la esencial heterogeneidad de toda sustancia. ${ }^{68}$

Por eso, la lógica poética tiene que procurar el adelgazamiento del yo, criticar radicalmente los signos de su exitosa presencia, signos que impiden el camino de encuentro con esa mismidad donde se descubre el amor como su propia

${ }^{66}$ Ibíd., S. XLII, I, p. 786. Cf. también: «Para ello necesitamos — sigue hablando Mairenaun hombre extraordinario, algo más que un ejemplar de nuestra especie; pero de ningún modo un maestro a la manera de Zaratustra, cuya insolencia ética biológica nosotros no podríamos soportar más de ocho días. Nuestro hombre estaría en la línea tradicional protagórico-socráticoplatónica, y también, convergentemente, en la cristiana» (Ibíd., p. 2055).

67 Aunque Machado no admita los excesos de objetividad, se impone ahora el recuerdo de Scheler: «el corazón posee algo estrictamente análogo a la lógica, en su propio dominio que, sin embargo, no coincide con la lógica del entendimiento... Existe un orden del corazón, una lógica del corazón, una matemática del corazón, tan rigurosa, tan objetiva, tan absoluta e inquebrantable como las proposiciones y consecuencias de la lógica deductiva» (Scheler, M.: Muerte y supervivencia, trad. Xavier Zubiri, Madrid, Revista de Occidente, 1934, pp. 141142). Cf. también «las composiciones de este primer libro (Soledades), publicado en enero de 1903, fueron escritas entre 1899 y 1902. Por aquellos años Rubén Darío, combatido hasta el escarnio por la crítica al uso, era el ídolo de una selecta minoría. Yo también admiraba al autor de Prosas Profanas, al maestro incomparable de la forma y de la sensación, que más tarde nos reveló la hondura de su alma en Cantos de vida y esperanza. Pero yo pretendí - y reparad en que no me jacto de éxitos sino de propósitos- seguir camino bien distinto. Pensaba yo que el elemento poético....(era) lo que pone el alma, si algo pone, o lo que dice, si algo dice, con voz propia en respuesta animada al contacto con el mundo. Y aun pensaba que el hombre puede sorprender algunas palabras de un íntimo monólogo, distinguiendo la voz viva de los ecos inertes; que puede también, mirando hacia dentro, vislumbrar las ideas cordiales, los universales del sentimiento. No fue mi libro la realización sistemática de este propósito; mas tal era mi estética entonces.» (MACHADO, A., o.c., p. 1593).

68 Ibíd., p. 685. 
impureza, como su deseo de plenitud más plena: la alteridad sin la cual el sí mismo se desvanece.

$$
\begin{aligned}
& \text { "No es el yo fundamental } \\
& \text { eso que busca el poeta, } \\
& \text { sino el tú esencial.» }{ }^{69}
\end{aligned}
$$

La crítica de las creencias será siempre el inicio de este adelgazamiento del yo, porque siempre requerirá la palabra del otro, la presencia del otro, la perspectiva del otro. No se trata de escepticismo; tampoco de una duda que pretenda abrir paso a la ciencia o a la fe; se trata de un amor sabio que rompe el «espejo de Narciso» y abre a la vida auténtica: diálogo en busca de verdad.

«Aprende a dudar, hijo, y acabarás dudando de tu propia duda. De este modo premia Dios al escéptico y confunde al creyente.» ${ }^{70}$

Se trata entonces, y Zambrano asume, no de negar la razón, sino precisamente de descubrir esos «universales del sentimiento», que presentes en la intimidad humana, y resistentes a toda negación, revelan la heterogeneidad de lo que es.

«La razón misma, se piensa, no podría ponerse en marcha si, en su camino de lo uno a lo otro, no creyera que lo otro no podía ser, al fin, eliminado. Y esto parece tan cierto como... lo contrario, a saber: que sin lo otro, toda actividad racional carecería de sentido. De modo que todo el trabajo de nuestra inteligencia va acompañado de dos creencias contradictorias: en la existencia y en la no existencia de lo otro.» ${ }^{71}$

Y la búsqueda de respuesta a este dilema, posible fundamento de todo diálogo fraterno, no podrá nunca encontrarse en la lógica eleática, ya que es ella quien lo provoca. Entonces la voluntad se ve obligada a tomar partido ${ }^{72}$. La

${ }_{69}$ Ibid., CLXI, XXXVI, p. 633.
70 Ibid., p. 2312.
71 Ibid., p. 2355.
72 "Frente a nuestra fe cristiana —una "videncia” como otra cualquiera- en un Dios paternal que nos ordena el amor de su prole, de la cual somos parte, sin privilegio alguno, milita la fe metafísica en el solus ipse que pudiéramos formular; "nada es en sí sino yo mismo, y todo lo demás, una representación mía, o una construcción de mi espíritu que se opera por medios subjetivos, o una simple constitución intencional del puro yo, etc., etc."; En suma, tras la frontera de mi yo empieza el reino de la nada. La heterogeneidad de estas dos creencias ni excluye su contradicción ni tiene reducción posible a denominador común. Y es en el terreno de los hechos... donde no admite conciliación alguna. Porque el ethos de la creencia metafísica es necesariamente autoerótico, egolátrico. El yo puede amarse a sí mismo con amor absoluto, de radio infinito. Y el amor al prójimo, al otro yo que nada es en sí, al yo representado en el yo absoluto, sólo ha de profesarse de dientes para fuera. A esta conclusión d'enfants terribles — ¿y qué otra cosa somos? - de la lógica hemos llegado. Y reparad ahora en que el "ama a tu prójimo como a ti mismo y aún más, si fuera preciso", que tal es el verdadero precepto cristiano, lleva implícita una fe altruista, una creencia en la realidad absoluta, en la existencia en sí del otro yo. Si todos somos hijos de Dios - hijosdalgo, por ende, y ésta es la razón del orgullo modesto a que he aludido más de una vez- ¿cómo he de atreverme, dentro de esta fe cristiana, a degradar a mi prójimo tan profunda y sustancialmente que le arrebate el ser en sí para convertirlo en mera representación, en un puro fantasma mío?» (Ibíd., pp. 2070-2071). 
alternativa ante la presencia de la alteridad se abre con suma fuerza: o voluntad de poder (dominio) o voluntad de hospitalidad (piedad/misericordia). Y aquí Machado realiza su arriesgada propuesta, que será oída por Zambrano: la voluntad de hospitalidad exigiría el «salto» a la «lógica cordial» de Cristo.

$$
\begin{aligned}
& \text { «Enseña el Cristo: a tu prójimo } \\
& \text { amarás como a ti mismo, } \\
& \text { mas nunca olvides que es otro. } \\
& \text { Dijo otra verdad: } \\
& \text { busca el tú que nunca es tuyo } \\
& \text { ni puede serlo jamás.»»3 }
\end{aligned}
$$

«Tal me parece a mí el sentido del Evangelio y la gran revelación del Cristo, el verdadero transmutador de valores. La humildad es un sentimiento cristiano, porque el amor que Cristo ordena es un amor sin orgullo, sin deleite en nosotros ni en nuestra obra; nosotros no podríamos engendrar el objeto de nuestro amor, a nuestro hermano, obra de Dios. El amor fraternal nos saca de nuestra soledad y nos lleva a Dios. Cuando reconozco que hay otro yo, que no soy yo mismo ni es obra mía, caigo en la cuenta de que Dios existe y de que debo creer en él como en un padre. Siempre me pareció que la filosofía moderna, habiendo instituido en dogma la necesidad de separar la razón de la fe, olvida demasiado la profunda significación del cristianismo. Hace de la filosofía una reflexión sobre la ciencia, sobre el pensamiento mismo, lo que, en resumidas cuentas, es una reacción hacia la vieja fe, hacia la superstición eleática que identifica el ser con el pensar. Pero, entonces, ¿a qué vino Cristo al mundo? Él nos reveló valores universales que no son de naturaleza lógica, los nuevos caminos de corazón a corazón por donde se marcha tan seguro como de un entendimiento a otro, y la verdadera realidad de las ideas, su contenido cordial, su vitalidad. Guerra a la naturaleza, este es el mandato de Cristo, a la naturaleza en sentido material, a la suma de elementos y de fuerzas ciegas que constituyen el mundo, y a la naturaleza lógica, que excluye por definición la realidad de las ideas últimas: la inmortalidad, la libertad, Dios el fondo mismo de nuestras almas. Confiamos/en que no será verdad/nada de lo que pensamos, creo haber dicho en una copla; pero me refería al pensar desustanciado y frío, al pensar que se mueve entre relaciones, entre límites, entre negaciones, al pensar por conceptos vacíos que no puede probar nada de cuanto alienta en nuestro corazón. El corazón y la cabeza no se avienen, pero nosotros hemos de tomar partido. Yo me quedo con el piso de abajo. ¡Guerra a Caín, viva el Cristo!» ${ }^{74}$

73 Ibid., XLII-XLIII, p. 634.

74 Ibíd., pp. 1601-1602 (el texto pertenece a una carta que Machado dirige a Unamuno desde Baeza el 16-1-1918 en agradecimiento por haber recibido su Abel Sánchez, «su agrio y terrible Caín». Obsérvese hacia donde dirige Machado su escepticismo - y conviene subrayar que es la época de Los Complementarios cuyo fruto, ya en Segovia, será recogido en sus apócrifos-). Machado se defiende con brillantez, remitiendo al quehacer de Sócrates, de aquellos que le consideran escéptico. No se trata de escepticismo, sino de derrotar todo pensar dogmático tanto religioso como civil. La declaración, fina ironía, de Machado es evidente cuando comenta su sueño nocturno con los alumnos: «la otra noche soñé, decía Juan de Mairena a sus alumnos — hacia 1909— que esta clase sin cátedra, reunión de amigos 
Entiéndase bien lo que se propone. No se trata, invito al lector a no caer en la crítica fácil, y menos leyendo a Machado, de proponer que la fe cristiana sea fundamento de la filosofía. Se trata de reconocer que en la palabra de Cristo se abre un verdadero camino de sabiduría, que no implica, sin más, una interpretación teológica de la conciencia o una inmediata conciencia de Dios; como tampoco de ofrecer ideas de razón como posibilidad de una comunidad racional; y, menos aún, el intento de una explicación de la intimidad humana desde leyes naturales/biológicas; sino de vivificar, por el diálogo, ese anhelo íntimo: deseo de alteridad, escondido entre las creencias superficiales, que la ironía, relativismo positivo, tiene el deber de despertar, para caminar sin que el yo único, original e irrepetible de cada cual quiera imponerse, porque «nadie es más que nadie» ${ }^{75}$, sobre los demás: comunidad humana real, amor. Porque sólo así cuando llegue...

«...porque le llegará... el inevitable San Martín al solus ipse, porque el hombre crea en su prójimo, el yo en el tú, y el ojo que ve en el ojo que le mira, puede haber comunión y aun comunismo ${ }^{76}$.

más que otra cosa, iba a ser suprimida de Real Orden. Toda una Real Orden para suprimir una clase voluntaria y gratuita... Lo cierto es que se me acusaba como al gran Sócrates - reparad un poco en la vanidad del durmiente- de corruptor de la juventud. La acusación era mantenida por un extraño hombrecillo, con sotana eclesiástica y tricornio de la Guardia Civil. "En los momentos solemnes - la voz del acusador era tonante y campanuda...- en los momentos solemnísimos en que media Europa se apercibe a trabarse con la otra media - y no de palabra - ... abandona usted su clase de Gimnástica... para iniciar a la juventud en toda suerte de ejercicios sofísticos — que esta es la palabra: ¡sofísticos! — para inficionarla del negro virus del escepticismo, aficionándola como usted llama, hipócritamente, al cultivo de las cabezas... Como si el cultivo de las cabezas... no fuese harto superfluo en las circunstancias actuales, y el más superfluo de todos los cultivos en las que se avecinan"... Lo verdaderamente original del ensueño - dijo un joven alumno muy avanzado en la sofística- no puede consistir en la supresión de una catedra gratuita, para lo cual basta con retribuirla, sino en la supresión de una cátedra voluntaria, que no puede convertirse en obligatoria. Porque, ¿quién pone puertas al campo, querido maestro?, ¿quién podrá impedir que nos reunamos en casa de usted? Sólo a un soñador, en efecto puede ocurrírsele cosa tan peregrina... En cuanto a la figura del acusador, todos estuvieron de acuerdo en que no habría por qué ataviar a la española - con sotana y tricornio- cosa tan universal como es la estupidez humana.» (Ibíd., pp. 2388-2391). Y como queda claro en la cita no hay tampoco escepticismo con respecto al problema de Dios. Sí, evidentemente anticlericalismo y pertenece al rigor intelectual distinguir el problema de Dios de los problemas de la clerecía. Lo que muestra Machado es la verdadera lucha del creyente: mantener la fe (presencia de Dios) sin posibilidad de adueñarse de Dios (señorío, otredad de Dios: ausencia psicológica de Dios), que exige, por eso, la espera (apertura al deber ser: hombre nuevo, ciudad nueva) que siempre, si es verdadera espera (discernimiento), se encarnará en «obras de amor» (caridad/justicia).

75 Ibid., p. 1932.

76 El concepto debe ser matizado. Detrás no está Marx, sino la literatura rusa y sobre todo Tolstoi: «Fue en Grecia, en la divina Atenas, y en la divina Atenas, cien veces sagrada, donde el hombre descubre y se adueña de su propia racionalidad, por el hábito de pensar en común. Al amparo de las democracias helénicas, los hombres libres, los ciudadanos, convierten el pensamiento en un hábito social, en una actividad de ágora, de plaza pública. El hombre libre opina, discute, polemiza, conversa, dialoga, contrasta su propio pensar con 
Y, así, la filosofía primera encuentra su camino. Se trata de mantener viva la llamada, voz íntima, que acontece en el interior de la vida humana precediendo y excediendo el libre compromiso del sujeto. Porque, quizá, la preocupación por el otro no comience por una decisión de la voluntad, sino por la Presencia/ Ausencia de un Otro que se hace presente exigiendo respetar al otro, exigiendo el orden del amor, piedad (Antígona) y misericordia (Nina de Galdós), para alumbrar la propia y verdadera personalidad.

Porque ese sentimiento común nacido de la Presencia/Ausencia, por eso voz, donada, regalada, no uniforma, como creen algunos, sino personaliza, hace a cada ser humano diferente de los demás y, por eso, invita, tiene que invitar, otra vez Unamuno, a superar los enfrentamientos entre «los Hunos y los Hotros», exigiendo caminos de diálogo que el amor a la sabiduría, la segunda tarea de la filosofía primera, tiene que saber fundar, mantener y recrear. Porque

«Si Cervantes hubiese hecho filosofía partiendo del fracaso de Don Quijote, si hubiese adoptado una actitud reformista para encontrar las bases de un nuevo conocimiento sistematizado, hubiese hallado las bases humanas de una nueva convivencia, un sentido del prójimo ausente por completo en la cultura europea, más ausente a medida que avanzaba el idealismo. La soledad esencial sobre la que se funda el idealismo, es en Don Quijote profunda, esencial convivencia; allí donde está su voluntad, allí está el otro, el hombre igual a él, su hermano por quien hace y arremete contra todo. El prójimo no es algo que sobreviene a la soledad del hombre, en nuestro Don Quijote, sino

el de su prójimo y averigua por sí mismo — no acepta como dogma- que las normas y categorías de su entendimiento no son individuales sino específicas, que revelan la común estructura del espíritu humano y que, por ello, hay verdades a las que todos los hombres pueden elevarse, porque son el fruto del pensar de todos: que existe una objetividad. Tal fue el resultado, más tarde, de la mayéutica socrática, del arte de patear espíritus, la gran conquista del genio helénico, realizada plenamente cuando la actividad del ágora pasó al jardín de Academos, donde disertaba el divino Platón. Pero el pueblo ruso, sometido hace años al imperio despótico de los zares, sin hábitos de ciudadanía, sin libertad política, no ha conocido aún, como tal pueblo, esta forma de eucaristía: la comunión de ideas... Buscaréis en vano un gran nombre ruso en la historia de los grandes sistemas de ideas. Falta hoy a Rusia metafísica propia, y una de las causas del fracaso de su gran revolución acaso sea el desmedido tributo que las mentalidades directoras de Rusia rinden necesariamente al pensamiento alemán, al determinismo económico de Carlos Marx. Pero hay otra forma de universalidad que no la expresa el pensamiento abstracto, que no es hija de la dialéctica, sino del amor, que no es de fuente helénica, sino cristiana: se llama fraternidad humana, y fue la gran revelación de Cristo... Los pueblos que alcanzaron un alto grado de prosperidad material - Francia, Alemania, Inglaterra, Italia - y también un alto grado de cultura (lo uno no va sin lo otro) tienen un gran momento de peligro en su historia, peligro que sólo la cultura misma puede remediar. Estos pueblos llegan a padecer una grave amnesia, olvidan el dolor humano. Su civilización es superficialidad, toma el sentido de la utilidad y del placer, olvidan esa tercera dimensión del alma humana, el fondo religioso de la vida, el sentimiento trágico de ella, que dice el gran Unamuno, dejan a un lado los problemas esenciales y paralizan, sin saberlo, los íntimos resortes de su misma civilización. La literatura rusa ha sido un enérgico y vibrante despertador, que nos desvela y ahuyenta de nosotros el sueño epicúreo.» (Ibíd., pp. 1235-1238. La nota es mía). 
que en su misma melancólica soledad está esencialmente el prójimo; cuanto más solo y lejos de los hombres, más unido y entregado por su voluntad a ellos. ${ }^{77}$

[Artículo aprobado para publicación en septiembre de 2019]

77 M. Zambrano, Los intelectuales en el drama de España, o.c., pp. 214-215. 